\title{
TNF in the liver: targeting a central player in inflammation
}

\author{
Gisa Tiegs $\mathrm{s}^{1,2}\left(\right.$ D $\cdot$ Andrea K. Horst ${ }^{1,2}$
}

Received: 18 November 2021 / Accepted: 12 January 2022 / Published online: 4 February 2022

(c) The Author(s) 2022

\begin{abstract}
Tumour necrosis factor- $\alpha$ (TNF) is a multifunctional cytokine. First recognized as an endogenous soluble factor that induces necrosis of solid tumours, TNF became increasingly important as pro-inflammatory cytokine being involved in the immunopathogenesis of several autoimmune diseases. In the liver, TNF induces numerous biological responses such as hepatocyte apoptosis and necroptosis, liver inflammation and regeneration, and autoimmunity, but also progression to hepatocellular carcinoma. Considering these multiple functions of TNF in the liver, we propose anti-TNF therapies that specifically target TNF signalling at the level of its specific receptors.
\end{abstract}

Keywords TNF signalling $\cdot$ Inflammation $\cdot$ Apoptosis $\cdot$ Viral hepatitis $\cdot$ Non-alcoholic fatty liver disease $\cdot$ Autoimmune hepatitis · Primary sclerosing cholangitis

\section{Introduction}

TNF is a pro-inflammatory cytokine critically involved in autoimmune diseases. Therefore, TNF inhibitory approaches successfully entered the clinic for therapy of e.g. rheumatoid arthritis (RA), psoriasis, and inflammatory bowel disease (IBD) [1]. Unfortunately, not all patients respond to antiTNF therapy. On the contrary, paradoxically and in rare cases, anti-TNF therapy can trigger autoimmune-like diseases such as a lupus-like syndrome or autoimmune hepatitis (AIH) [2] and might induce drug-induced liver injury (DILI) [3]. These clinical observations are probably due to the pleiotropic molecular properties of TNF. TNF induces inflammation, apoptosis, and necroptosis, but also cell survival and proliferation primarily via activation of its ubiquitously expressed TNF receptor 1 (TNFR1) [2].

This article is a contribution to the special issue on: Tolerance and autoimmunity in the liver-Guest Editor: Christoph Schramm, Ansgar Lohse \& Ye Oo

Gisa Tiegs

g.tiegs@uke.de

1 Institute of Experimental Immunology and Hepatology, University Medical Center Hamburg-Eppendorf, Hamburg, Germany

2 Hamburg Center for Translational Immunology, University Medical Center Hamburg-Eppendorf, Hamburg, Germany
In the liver, TNF mediates hepatocellular death and seems to be involved in sterile inflammation, viral hepatitis, AIH, and hepatocellular carcinoma (HCC) [4-7]. The multifunctional properties of TNF in the liver apparently result from activation of a multitude of downstream signals resulting in functionally different, sometimes contrary cellular responses such as cell death and inflammation on the one hand, and cell survival on the other hand. These properties of TNF make it necessary to study the exact molecular function of TNF and its receptors in a specific hepatic disease to identify the most relevant target for therapeutic intervention.

\section{TNF signalling}

TNF is produced as a $26-\mathrm{kDa}$ transmembrane precursor protein (mTNF) that is proteolytically cleaved by TNF-converting enzyme (TACE, ADAM17) to generate a soluble 17-kDa protein (sTNF). Both sTNF and mTNF are bioactive and signal as homotrimers via two structurally distinct membrane receptors, p55 TNFR1 and p75 TNFR2, which are trimerized upon ligand binding [8]. While TNFR1 is ubiquitously expressed, TNFR2 expression is essentially restricted to haematopoietic and endothelial cells during homeostasis and can be further induced in response to inflammation. mTNF, as well as STNF, can stimulate TNFR1, while TNFR2 is preferentially activated by mTNF. Binding of TNF to TNFR1, which contains a death domain, 
results in the formation of complex I which consists of the membrane-bound signalling core TNFR1-TNFR1-associated death domain (TRADD)-receptor-interacting protein kinase (RIPK) 1-TNF receptor-associated factor (TRAF) 2 (Fig. 1). TRAF2 binds to the cellular inhibitors of apoptosis proteins 1 (cIAP1) and 2 (cIAP2). Polyubiquitin chains added to this complex assure appropriate protein scaffolding and downstream signal activation. Formation of complex I results in the activation of TGF $\beta$-activated kinase 1 (TAK1) which further activates c-Jun $\mathrm{N}$-terminal kinase (JNK)/ p38 signalling as well as the inhibitor of $\kappa \mathrm{B}(\mathrm{IkB})$ kinase
(IKK). The IKK complex consists of three subunits, IKK $\alpha$, $\mathrm{IKK} \beta$, and the regulatory subunit nuclear factor $\kappa \mathrm{B}(\mathrm{NFKB})$ essential modulator (NEMO, also known as IKK $\gamma$ ). Once

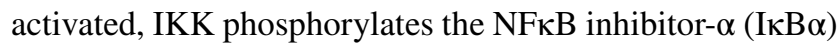
which is degraded upon K48-linked polyubiquitinylation, finally allowing the transcription factor NFKB to translocate into the nucleus and to activate transcription of numerous of its target genes involved in inflammation, cell survival, and proliferation [2, 8]. Homozygote mice lacking the p65/ RelA component of NFKB exhibit embryonic lethality due to massive liver degeneration [9]. Moreover, NFKB mediates

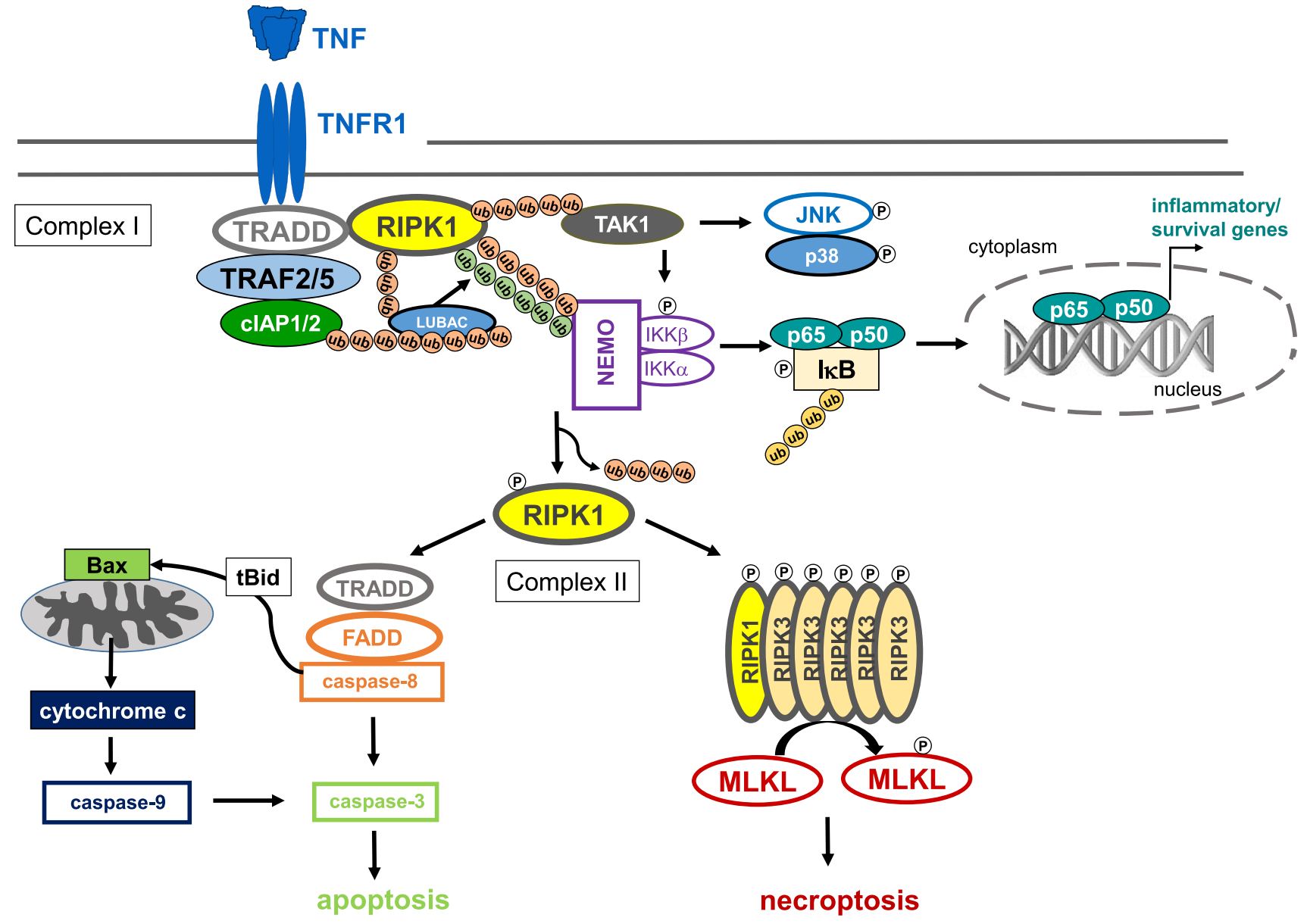

Fig. 1 TNFR1 signalling. Binding of TNF to TNFR1 results in the formation of complex I which consists of the membrane-bound adaptor molecules TNFR1-TRADD-RIPK1-TRAF2 or TRAF5 that associate with the E3 ubiquitin ligases cIAP1 and cIAP2, which add K63-linked polyubiquitin chains to RIPK1 and other components of the signalling complex. This results in recruitment of linear ubiquitin chain assembly complex (LUBAC), which adds M1-linked linear polyubiquitin chains to RIPK1. Subsequently, via activation of TAK1, the Jun/p38 signalling pathways as well as the IKK complex, consisting of IKK $\alpha$, IKK $\beta$, and the regulatory subunit NEMO, are acti-

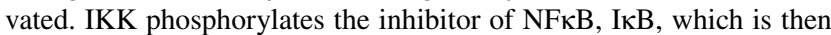
degraded following $\mathrm{K} 48$ polyubiquitination, giving rise to activated $\mathrm{NFKB}$ and its translocation into the nucleus. By binding to specific promoter regions of cytokine and chemokine genes, but also for genes of anti-apoptotic, cytoprotective proteins (see text for details), NFKB mediates either inflammation or cell survival. Upon recruitment of FADD to TRADD, the death-inducing signalling complex (complex II) is formed, which in turn recruits pro-caspase 8 to finally execute the proapoptotic downstream pathway of TNFR1. In hepatocytes, TNF-induced apoptosis requires the activation of the mitochondrial pathway that involves cleavage of $\mathrm{BH} 3$ interacting-domain death agonist (Bid) to truncated Bid (tBid), activation of Bax, formation of mitochondrial permeability transition pores, release of cytochrome $\mathrm{c}$ from the mitochondria, and finally activation of caspase 9 and caspase 3. Alternatively, in the presence of phosphorylated RIPK1, RIPK 3 can be recruited into the complex which in turn phosphorylates MLKL to induce necroptosis. Necroptotic cell death is caspaseindependent and represents a pro-inflammatory form of cell death 
liver regeneration that requires activation of TNFR1 but not TNFR2 (cf. Fig. 2) [10, 11]. The cytoprotective effects of TNF are mediated by NFkB-inducible anti-apoptotic proteins such as cIAPs, cellular FLICE-like inhibitory protein (c-Flip), A20, X-chromosome linked inhibitor of apoptosis protein (XIAP), and B cell lymphoma-extra large $\left(\mathrm{Bcl}-\mathrm{X}_{\mathrm{L}}\right)$, most of them interacting with signalling molecules of the death signalling pathway [12].

The death-inducing signalling complex (complex II) is formed upon recruitment of Fas-associated death domain (FADD) to TRADD, which in turn recruits pro-caspase 8 to finally execute the proapoptotic downstream pathway of TNFR $1[2,8]$. Activated caspase 8 proteolytically cleaves pro-caspase 3 to activate the executer caspase 3 , which could be sufficient to mediate apoptosis. In hepatocytes, TNF-induced activation of caspase 3 requires additional signals of a mitochondrial pathway that involves activation of $\mathrm{Bcl}-2$-associated $\mathrm{X}$ protein (Bax), a proapoptotic member of the B cell lymphoma 2 (Bcl-2) family, formation of mitochondrial permeability transition (MPT) pores, and release of cytochrome c [5, 13]. Alternatively, in the presence of phosphorylated RIPK1, RIPK3 can be recruited into the complex which in turn phosphorylates mixed lineage kinase domain-like protein (MLKL) to induce necroptosis. Necroptotic cell death is caspase-independent and represents a pro-inflammatory form of cell death (Fig. 1) $[2,8]$. TNFR2 does not contain a death domain and therefore cannot induce cell death. However, via recruitment of TRAFs, TNFR 2 activates NFKB and thereby induces inflammation and cell survival $[2,8]$. Notably, substantial evidence points to a role for TNFR2 in regulatory $\mathrm{T}$ cell (Treg) expansion, immunosuppressive function, and stability (Fig. 2) [14, 15].

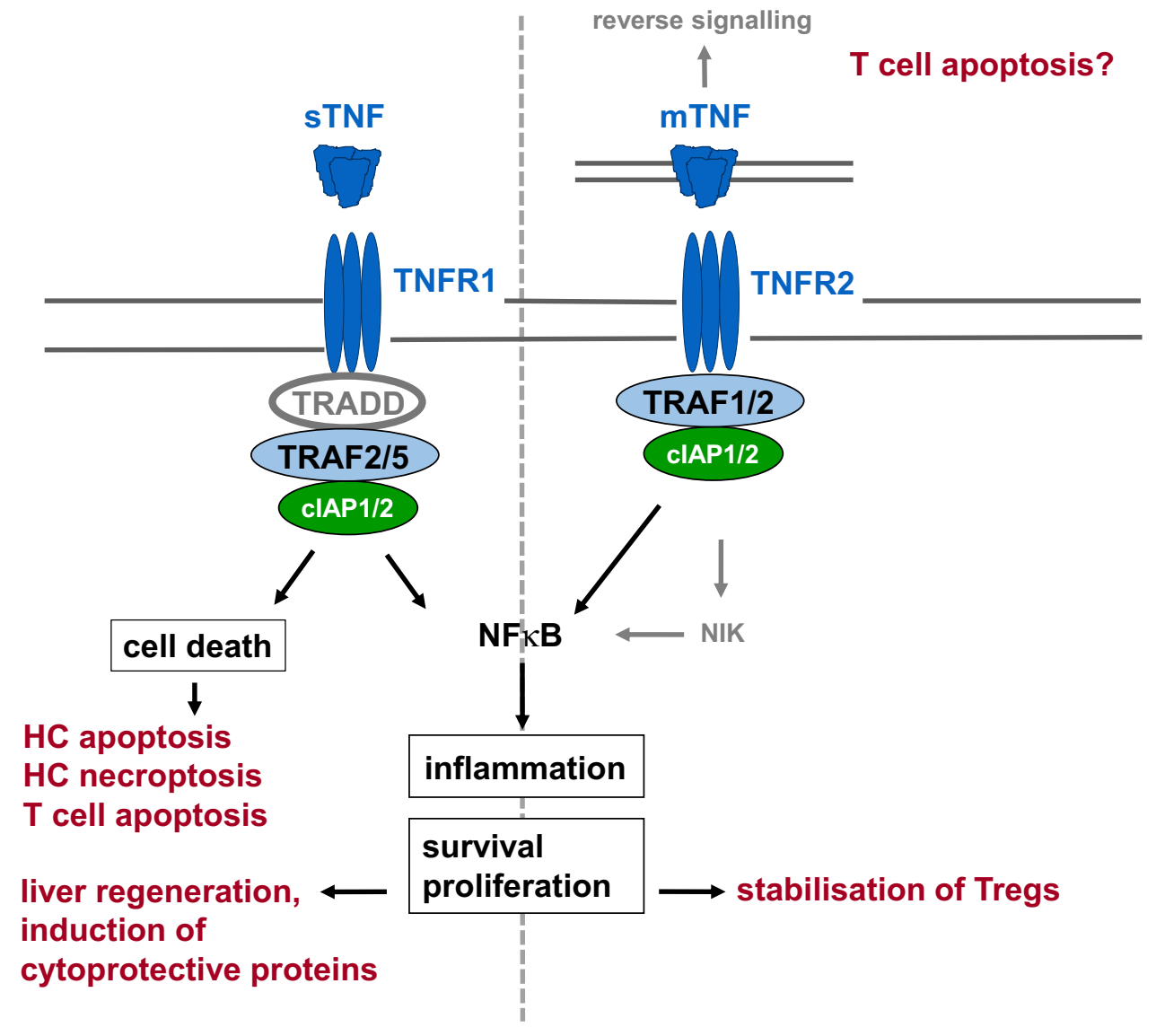

Fig. 2 Overview of the different functions of TNFR1 and TNFR2. TNFR1 is activated by sTNF and mTNF whereas TNFR2 is preferentially activated by mTNF. TNFR1 contains a death domain and can therefore execute cell death signals. TNFR1 signalling that leads to the activation of NFKB (cf. Fig. 1) mediates inflammation as well as cell survival and proliferation. TNFR2 does not contain a death domain. Recruitment of TRAF1 and 2 as well as cIAP1 and 2 to the intracellular domain of TNFR2 results in canonical and, via activa- tion of NFKB-inducing kinase (NIK), to non-canonical NFKB activation. Besides induction of inflammation, cell survival, and proliferation, TNFR2 was supposed to cooperate with TNFR1 to induce cell death by down-modulation of TRAF2 and cIAPs, thereby inhibiting the anti-apoptotic NFkB signalling pathway (not shown, see text). Moreover, it has been assumed that mTNF might function as receptor for an activating antibody, thereby inducing apoptosis by reverse signalling (see text) 


\section{TNF mediates hepatocellular death}

In 1975, Carswell et al. [16] characterized the serum factor that has been described to mediate necrosis of solid tumours caused by bacterial toxins, i.e. endotoxin or lipopolysaccharides (LPS), and named it TNF. TNF was toxic for neoplastic cell lines but not for mouse embryonic cells. Later, it was shown that D-galactosamine (D-GalN), a transcriptional inhibitor, sensitizes wild-type mice to lethal toxicity of LPS and TNF [17] and that administration of either LPS or TNF to D-GalN-sensitized mice caused fulminant hepatitis [18]. D-GalN is primarily metabolized in hepatocytes where it depletes uridine nucleotides and thereby functions as transcriptional inhibitor [19]. Transcriptional inhibition sensitised hepatocytes towards induction of apoptosis in response to TNF [20], an effect that is mediated by TNFR1 (Figs. 1 and 2) [21, 22]. Pretreatment of mice with TNF alone, without transcriptional inhibition, protected them from apoptotic liver damage subsequently induced by D-GalN/TNF administration, an effect that was mediated by TNF-inducible NFkB-dependent cytoprotective proteins such as A20, which inhibited TNF-induced mitochondrial apoptosis in the mouse liver by down-modulation of Bax [23, 24]. Moreover, interference with linear polyubiquitination of RIPK1 in complex I that is necessary for TNFR1-mediated NFKB activation sensitised hepatocytes to TNF-induced apoptosis even in the absence of transcriptional inhibition and exacerbated TNF-mediated liver damage in mice [25]. In addition, the protective effect of TNF administration was most likely mediated by TNFR1, since nuclear translocation of NFKB was almost completely inhibited in $T n f r 1^{-/-}$mice but fully inducible in $T n f r 2^{-/-}$mice following combined activation of both TNF receptors in the murine liver (cf. Fig. 2) [26, 27].

Besides induction of hepatocellular apoptosis, TNF induces necroptosis in the mouse liver in models of inflammatory liver injury (Figs. 1 and 2). In the mouse model of concanavalin A (ConA)-induced hepatitis, which depends on activation of $\mathrm{CD}^{+}{ }^{+} \mathrm{T}$ cells and NKT cells $[28,29]$, TNF mediates liver damage independently of transcriptional inhibition [30]. Notably, in ConA-hepatitis, TNF mediates liver injury in its soluble and transmembranebound precursor form that depends on activation of both TNF receptors [27].

In this model, TNF induces caspase-8- and caspase3 -independent liver cell death [31-33] which is probably mediated by prolonged JNK activation [32, 34]. Notably, the JNK pathway has been implicated in both hepatocyte proliferation and apoptosis (reviewed in [35]). Liver cell death in the ConA-model resembles necroptosis, as the disease-associated molecular pattern (DAMP) IL-33, which is associated with necroptotic cell death, is released from hepatocytes upon ConA treatment [36, 37]. Moreover, inhibitors of necroptosis protected mice from ConAinduced liver injury [38].

Until now, a role of TNFR2 for liver injury was scarcely described. In 1998, Douni and Kollias [39] reported that mice transgenic for the human TNFR2 developed a severe inflammatory syndrome, including inflammatory liver disease even in the absence of endogenous TNFR1, which supported the notion that TNFR2 primarily drives inflammation by increased NFKB activation. However, in a model of immune-mediated liver injury that depends on both TNF receptors, we provided evidence for cooperative cell death signalling of TNFR 1 and TNFR 2 by showing that bone marrow chimeric mice that express TNFR2 in leucocytes but not in parenchymal cells were protected from liver damage [40]. Mechanistically, cooperative cell death signalling of both TNFRs was explained by TNFR2-induced down-modulation of TRAF2 and cIAPs, thereby affecting the TNFR1-dependent anti-apoptotic NFkB signalling pathway [41].

\section{Contribution of TNF to sterile liver inflammation}

\section{Acetaminophen}

The prominent role of TNF for induction of liver cell death prompted many investigators to study the role of TNF and its receptors in liver disease, liver regeneration, and HCC in mouse models and in patients' studies (summary of major TNF effects in Table 1). The term sterile liver inflammation was established by showing that the NLR family pyrin domain containing 3 (NLRP3) inflammasome contributed to liver damage without infection, e.g. inducible by the anti-pyretic and analgesic drug acetaminophen (APAP, $N$-acetyl-4-aminophenol; reviewed in [42]). APAP is one of the most commonly used over-the-counter drugs taken worldwide. APAP induces acute liver failure upon suicidal intent or unintentional overdose [43]. Sterile inflammation in the liver is triggered in response to hepatocyte death probably induced by RIPK3-mediated necroptosis [44], which results in the release of DAMPS such as high-mobility group box 1 protein (HMGB1), heat shock proteins (HSPs), and DNA fragments (reviewed in [45]). DAMPS activate toll-like receptors (TLRs) expressed by monocytes/macrophages and activate a pro-inflammatory response via release of cytokines and chemokines [45]. Although, despite production of pro-inflammatory cytokines such as IL-1 $\beta$, IL-6, and TNF, TNF-deficient mice were not protected from APAP liver toxicity [46] and mice lacking TNFR1 even developed aggravated liver 
Table 1 Major effects of TNF on liver pathology

\begin{tabular}{ll}
\hline Liver disease & Major TNF effect \\
\hline $\begin{array}{l}\text { APAP-induced liver damage } \\
\text { Alcoholic liver disease (ALD) }\end{array}$ & Tissue repair [45] \\
$\begin{array}{l}\text { Non-alcoholic fatty liver disease (NAFLD) } \\
\text { and non-alcoholic steatohepatitis }\end{array}$ & $\begin{array}{l}\text { Increased serum levels and hepatic expression of TNF and TNFR1, correlating with disease activity } \\
\text { in NASH patients [64-66], }\end{array}$ \\
& TNFR1-dependent attenuation of insulin resistance and liver injury in a mouse model [68], \\
& Normalisation of liver biochemistry in a NASH patient treated with adalimumab for co-existing RA \\
Viral hepatitis & [69] \\
HBV & Induction of cell death in HBV-infected hepatocytes, NFkB-dependent blockade of HBV replication \\
& [75, 83, 85] \\
HCV & Induction of apoptosis in HCV-infected Huh-7.5 cells [77] \\
Autoimmune liver disease & \\
AIH & TNF polymorphism associated with type 1 AIH susceptibility [93], \\
PBC & Successful treatment of AIH with infliximab [6] \\
& Pathway analysis provided evidence for enhanced TNF signalling in PBC pathogenesis [87], \\
& Stabilisation of liver function in PBC patients treated with TNF antagonists for co-existing RA [90, \\
PSC & High expression levels of TNF in innate-like CD4 ${ }^{+}$T cells from PSC patients [113], \\
& Moderate effectiveness of anti-TNF therapies in PSC/IBD patients [114, 115]
\end{tabular}

$A I H$, autoimmune hepatitis; $A P A P$, acetaminophen; $H B V$, hepatitis B virus; $H C V$, hepatitis $\mathrm{C}$ virus; $I B D$, inflammatory bowel disease; $P B C$, primary biliary cholangitis; $P S C$, primary sclerosing cholangitis; $R A$, rheumatoid arthritis; $T N F$, tumour necrosis factor; TNFR, TNF receptor

damage [47]. These findings point to a beneficial role of TNF most likely initiating tissue repair in response to APAP-induced liver damage [45].

\section{Alcoholic liver disease (ALD)}

ALD is one of the most common causes of chronic liver disease worldwide that may progress from alcoholic steatohepatitis to fibrosis, cirrhosis, and HCC [48]. Metabolic products of alcohol could directly cause liver cell death. Moreover, epithelial barrier disruption in the gut due to intestinal microbial dysbiosis, bacterial translocation, and increased LPS concentrations in the portal blood are considered to be responsible for activation of the innate immune response in the liver, which is associated with an increased production of pro-inflammatory cytokines such as TNF [48]. Indeed, RIPK3-dependent necroptosis was shown to be responsible for murine ALD [49]. Moreover, results from animal studies using either TNF neutralizing antibodies or TNFR1-deficient mice provided evidence for protection from chronic alcohol exposure [50, 51]. However, a multicentre clinical trial using the dimeric TNFbinding fusion protein etanercept as a treatment of patients with moderate to severe alcohol hepatitis failed because of serious adverse events such as increased infection rates and a significantly higher mortality rate after 6 months [52], clearly indicating that TNF blockade is not suitable for treatment of patients with ALD.

\section{Non-alcoholic fatty liver disease (NAFLD)}

Due to the growing incidence of obesity worldwide, NAFLD is a major cause of chronic liver disease with increasing prevalence. NAFLD is characterized by hepatic steatosis which may progress to non-alcoholic steatohepatitis (NASH) and development of fibrosis, cirrhosis, and HCC [53]. Co-morbidities are frequent and comprise the metabolic syndrome, insulin resistance, hypertension, and increased cardiovascular risk [53]. Multiple metabolic pathways are affected during NAFLD including metabolism of glucose, lipids, amino acids, and bile acids (BA). Within the liver, metabolic deterioration results in lipotoxicity, mitochondrial dysfunction, and endoplasmatic reticulum (ER) stress that induce apoptosis, necroptosis, and probably other types of lytic cell death in hepatocytes [54]. In response to cell lysis, released DAMPS activate their receptors expressed by macrophages and/or hepatocytes and induce inflammation. HMGB1 activates TLR4, DNA fragments TLR9, and ATP, the NLRP3-inflammasome amplifying receptor P2X7 [42, 55]. In addition, NAFLD/ $\mathrm{NASH}$ is associated with intestinal dysbiosis, probably resulting from intake of an inconvenient diet, which leads to a dysfunction of the epithelial barrier in the gut, associated with increased permeability and translocation of bacteria and bacterial products into the portal blood. Bacterial products such as LPS that function as pathogen-associated molecular patterns (PAMPs) also activate TLRs, thereby amplifying the inflammatory response in the 
liver, characterized by increased production of cytokines such as TNF, IL-1, and IL-17A as well as the chemokines CCL2 and CCL5 that further recruit inflammatory monocytes into the liver [53, 56, 57]. Moreover, changes in BA metabolism, associated with enhanced systemic levels of potentially cytotoxic BA, have been identified in NASH patients (reviewed in [58]). Altered ratios of primary to secondary BA levels underscore the impact of microbial alterations in the gut of NASH patients [59]. In addition, expression of enzymes for BA synthesis and BA transporters has been shown to be regulated by cytokines such as TNF and interferon- $\gamma$ [60]. Interestingly, BA receptors such as the nuclear farnesoid $\mathrm{X}$ receptor (FXR), the Takeda $\mathrm{G}$ protein-coupled receptor 5 (TGR5 also known as $\mathrm{G}$ protein-coupled BA receptor 1 (GPBAR1)), and the vitamin $\mathrm{D}$ receptor (VDR) have anti-inflammatory and immune-regulatory properties by shaping the innate and the adaptive immune system (reviewed in Evangelakos et al. [58]). Therefore, numerous FXR agonist such as obeticholic acid entered clinical trials for therapy of NASH [53, 56, 58, 61].

TNF is a mediator of insulin resistance in obesity, where it is overexpressed in adipose tissue and induces the release of the pro-inflammatory lipokine leptin from adipocytes [62, 63]. In NAFLD/NASH patients, elevated serum concentrations of TNF and soluble TNFR1 have been determined, which were associated with disease severity [64, 65]. Moreover, increased expressions of TNF in the liver and adipose tissue as well as enhanced hepatic TNFR1 transcripts were detected in NASH patients, again correlating with disease progression [66]. In a NASH mouse model, where wild-type and TNFR1/TNFR2-double knockout mice were fed a methionine and cholinedeficient diet, Kupffer cell activation and expression of pro-inflammatory molecules were significantly suppressed upon TNFR deficiency. Accordingly, hepatic stellate cell activation, liver steatosis, and fibrosis were attenuated in these animals [67]. In a recent report, Wandrer et al. [68] administered a high-fat diet to humanized TNFR1 knockin and control mice for 24 weeks before they started a therapeutic intervention with an anti-human TNFR1 antibody for another 8 weeks. This curative treatment, specifically blocking TNFR1, significantly reduced the activation of the mitogen-activated protein kinase (MAPK) pathway in the liver, insulin resistance, liver injury, steatosis, and fibrosis [68]. Hence, blockade of TNFR1 might represent a promising approach for treatment of NASH. In a case report, Schramm and co-workers reported a patient with NASH who developed rapid normalisation of liver biochemistry during treatment of an associated RA with the humanized anti-TNF antibody adalimumab [69]. However, up to now, clinical trials targeting TNF or its receptors as a therapy for NAFLD/NASH are not available.

\section{Role of TNF in viral hepatitis}

Infection with hepatitis B virus (HBV) and hepatitis C virus (HCV) elicits an antiviral immune response characterized by an innate type I interferon response and an innate (NK cells) and adaptive cellular immune response ( $\mathrm{T}$ cells). The cellular response eliminates infected hepatocytes by induction of apoptosis, elicited either by members of the TNF superfamily such as Fas ligand or TNF-related apoptosis-inducing ligand (TRAIL) or by granzyme B and perforin. However, activated effector $\mathrm{CD} 8^{+} \mathrm{T}$ cells also release TNF and other cytokines upon antigen recognition which facilitate viral control [70]. Although protective in principle, a sustained antiviral immune response mediates the immunopathogenesis of chronic viral hepatitis, as the viruses themselves are not cytopathic. With respect to $\mathrm{HBV}$ infection, polymorphisms in the TNF promoter region affect the susceptibility towards chronicity and disease pathology of hepatitis B (summarized in [71]).

Since HBV and HCV do not infect murine hepatocytes in vivo, several cellular studies analysed the role of viral proteins for sensitisation towards TNF-induced hepatocyte killing. For example, transfection of the HBV proteins $\mathrm{HBx}$ or HBV core protein $(\mathrm{HBc})$ sensitized cell lines towards TNF-induced apoptosis [72, 73]. Besides its role for induction of cell death in $\mathrm{HBV}$-infected hepatocytes, TNF directly controls HBV infection by blocking HBV replication through destabilisation of the viral nucleocapsid and decay of cccDNA [74], an effect that was reported to depend on NFKB activation [75] and c-Flip expression [76]. In an in vitro HCV infection model with Huh-7.5 cells, Park J et al. [77] demonstrated that HCV-infected cells were susceptible towards TNF-induced apoptosis compared to uninfected cells. Interestingly, HCV infection inhibited TNF-induced activation of IKK, nuclear translocation of NFKB, and expression of NFKB-dependent anti-apoptotic proteins, such as c-FLIP, XIAP, and Bcl$\mathrm{x}_{\mathrm{L}}$. mRNA transcripts of these anti-apoptotic proteins were also significantly reduced in liver tissue of patients with chronic hepatitis $\mathrm{C}$ compared to non-viral hepatitis. Transfection experiments revealed that TNF sensitisation of HCV-infected Huh-7.5 cells was probably mediated by the core, non-structural HCV proteins (NS)4B and NS5B [77].

Several studies analysed molecular and immunological mechanisms of TNF signalling during viral hepatitis in mouse infection models. TNF has been shown to promote hepatitis in murine hepatitis virus (MHV) infection as $\mathrm{Tnfrl}^{-/-}$mice displayed less hepatic apoptosis and necrosis, and reduced neutrophil infiltration into the infected liver as well as prolonged survival [78]. The hepatoprotective effect of TNF in MHV infection seemed 
to be mediated by activation of NFKB in liver parenchymal cells, since conditional knockout mice that specifically lack RIPK1 in hepatocytes developed more severe hepatocellular damage and an aggravated inflammatory response. Hence, RIPK1 deficiency in hepatocytes mimicked the TNF response observed in presence of transcriptional inhibition by D-GalN [79].

In a recent study, Lampl and co-workers [80] provided evidence for a TNF-inducible, cell-autonomous mechanism that selectively eliminates virus-infected hepatocytes. This effect was observed in mice infected with a hepatotropic recombinant adenovirus and was mediated by TNFR1, but not by TNFR2, upon TNF challenge. Activation of immune cells by TNF or by the virus was not required. The cellautonomous role of TNF was proven by administration of a Cre-recombinase encoding adenovirus that selectively deleted TNFR1 in infected hepatocytes of Tnfr f $^{\text {flox/flox }}$ mice. In these animals, TNF challenge failed to induce liver damage. In TNFR1 expressing hepatocytes, TNF induced cleavage of caspases 8, 9, and 3. However, administration of the Cre-recombinase encoding adenovirus to $\operatorname{Casp} 8^{f l o x / f l o x}$ mice failed to attenuate liver damage upon TNF injection, indicating that the observed mode of cell death was independent of caspase 8 . Notably, the authors neither observed necroptosis, pyroptosis, ferroptosis, nor oxeiptosis upon TNF injection to adenovirus-infected mice. However, inhibitor studies and studies using genetically modified mice or calcium scavengers as well as determination of the mitochondrial membrane potential provided evidence for a reactive oxygen species (ROS) and calcium-dependent deterioration of the mitochondrial membrane potential of infected hepatocytes exposed to TNF in vivo, indicating that TNF-induced cell death in adenovirus-infected mice was characterized as a caspase 8-independent, MPT-dependent, non-canonical type of hepatocyte apoptosis.

Although TNF seems to control viral hepatitis by induction of cell death in virus-infected hepatocytes, TNF signalling might also favour viral persistence by impairment of the antiviral $\mathrm{T}$ cell response, either by induction of $\mathrm{T}$ cell apoptosis [81] or by enhancing $\mathrm{T}$ cell inactivation, also known as $\mathrm{T}$ cell exhaustion [82]. $\mathrm{Tnfr1^{-/ }}$ mice showed increased numbers of virus-specific memory $\mathrm{CD} 8^{+} \mathrm{T}$ cells upon infection with the hepatotropic lymphatic choriomeningitis virus (LCMV), compared to $T n f r 2^{-/-}$mice [81]. Interestingly, mice that lack both TNF receptors showed an even higher increase of LCMV-specific $\mathrm{CD} 8^{+} \mathrm{T}$ cell numbers. TNF receptor deficiency did not affect proliferation but rather reduced apoptosis of LCMV-specific CD8 ${ }^{+}$ $\mathrm{T}$ cells, pointing to a role of TNF for $\mathrm{T}$ cell contraction during chronic viral infection. In another study, LCMVspecific $\mathrm{T}$ cells from chronically infected mice displayed increased expression of programmed cell death (PD)-1 and other co-inhibitory molecules, indicating enhanced
T cell exhaustion [82]. Treatment of chronically infected mice with the anti-TNF antibody infliximab resulted in an increase of $\mathrm{LCMV}$-specific $\mathrm{CD} 4^{+}$and $\mathrm{CD} 8^{+} \mathrm{T}$ cells, a concomitant reduction of PD-1 expression, and enhanced antigen-specific cytotoxicity of $\mathrm{CD} 8^{+} \mathrm{T}$ cells along with an improved control of viral infection. Interestingly, neutralization of TNF resulted in elevated levels of serum transaminases which was probably due to $\mathrm{T}$ cell-mediated hepatitis. The relevance of TNFR signalling for $\mathrm{T}$ cell immunity was analysed by adoptive transfer of $\mathrm{CD}^{+}$and $\mathrm{CD}^{+} \mathrm{T}$ cells from acutely infected wild-type or TNFR1/ TNFR2 double knockout mice into chronically infected animals. Analysis of the transferred T cells demonstrated significantly increased frequencies of LCMV-specific TNFR-deficient $\mathrm{T}$ cells compared to wild-type $\mathrm{T}$ cells, decreased frequencies of PD- $1^{+} \mathrm{T}$ cells, and a concomitantly enhanced ability of TNFR-deficient $\mathrm{T}$ cells to clear the virus. Using transgenic mice, the authors demonstrated that continuous NFkB activation in LCMV-specific CD4 ${ }^{+}$ $T$ cells resulted in increased PD-1 expression and impaired helper function in infected mice, which resulted in substantially lower frequencies and reduced effector functions of LCMV-specific CD8 ${ }^{+} \mathrm{T}$ cells. Accordingly, the authors discovered NFKB responsive elements in the PDCDI locus. Together this study indicates that continuous NFKB activation in $\mathrm{CD}^{+}{ }^{+} \mathrm{T}$ cells may provide a molecular link between TNF and T cell exhaustion during chronic viral infection. However, blockade of TNF during viral hepatitis might be contraindicated not only because of the welldocumented side effects of reactivation of quiescent infections but also because of restricted elimination of infected hepatocytes.

In an immunocompetent mouse model of chronic HBV infection, using hydrodynamic injection of a HBV plasmid to wild-type and cIAP1 and 2-deficient mice, it was shown that cIAPs, which are activated in the TNFR-dependent NFKB pathway, attenuated TNF-induced cell death of $\mathrm{HBV}$-infected hepatocytes, thereby allowing viral persistence [83]. Accordingly, inhibition of the function of IAPs by drug inhibitors of cIAPs, known as Smac mimetics, since they mimic the action of the endogenous protein Smac/Diablo that antagonises cIAP function, promoted the elimination of HBV [84]. In a similar mouse model of $\mathrm{HBV}$-infected immunocompetent mice, TNF neutralisation by etanercept impaired viral clearance of HBV, associated with a higher number of intrahepatic $\mathrm{PD}-1^{\text {high }} \mathrm{CD} 127^{\text {low }}$ exhausted CD ${ }^{+} \mathrm{T}$ cells [85]. Although there might exist virus-specific differences between LCMV and HBV infection regarding TNF-mediated exhaustion of helper and effector $\mathrm{T}$ cells, future studies are needed to elucidate the role of TNF and its receptors for T cell exhaustion during viral hepatitis. 


\section{Role of TNF in autoimmune liver disease (AILD)}

\section{Autoimmune hepatitis (AlH) and primary biliary cholangitis (PBC)}

Despite the unknown aetiology of AILD, genome-wide association studies provided evidence for a strong association of AILD with human leucocyte antigen (HLA) loci, emphasizing a critical role of adaptive $\mathrm{T}$ cell responses in the immunopathogenesis of AILD [86, 87]. Preclinical studies using TNF neutralisation or $T n \mathrm{fr}^{-/-}$and Tnfr $2^{-/-}$mice provided considerable evidence for a pathogenic role of TNF in acute T cell-dependent liver injury [27, 30, 40, 88, 89]. Pathway analysis in $\mathrm{PBC}$ patients provided evidence for the importance of TNF signalling [87]. Moreover, few clinical studies reported successful results of anti-TNF treatment in patients with RA and co-existing $\mathrm{PBC}[90,91]$. In patients with autoimmune hepatitis (AIH), increased frequencies of TNF-producing $\mathrm{CD}^{+} \mathrm{T}$ cells were detectable in peripheral blood and liver biopsy specimens compared to healthy controls. As the majority of $\mathrm{TNF}$-producing $\mathrm{CD}^{+} \mathrm{T}$ cells also produced IFN $\gamma$, the authors concluded that these cells are pathogenically activated Th1 cells. Indeed, antigen-specific activation of $\mathrm{T}$ cells resulted in significant TNF production by $\mathrm{CD}^{+}{ }^{+} \mathrm{T}$ cells from $\mathrm{AIH}$ patients who developed the corresponding antigen-specific antibody response [92]. In addition, a polymorphism in the TNF gene was associated with reduced remission, increased treatment failure, and enhanced incidence of liver cirrhosis in patients withtype 1 AIH compared to normal subjects [93]. Intriguingly, anti-TNF therapy (infliximab) of AIH patients not responding to standard treatment resulted in a significant reduction of serum transaminases and immunoglobulins [6]. Since anti-TNF treatment can be accompanied by infectious complications, the authors recommended infliximab as a rescue treatment for patients with severe and difficult-to-treat AIH. The mechanism of action of infliximab was discussed as neutralisation of soluble and transmembrane TNF and induction of apoptosis of activated lymphocytes. Indeed, besides inhibition of the production of other pro-inflammatory cytokines, anti-TNF antibodies induce apoptosis of mucosal T cells from Crohn's disease patients, for example by direct activation of caspase-3 in activated $\mathrm{CD}^{+} \mathrm{T}$ cells, which is probably mediated by reverse signalling via $\mathrm{mTNF}$, that can function as a receptor of the antibody (cf. Fig. 2) [94]. Hence, it could be speculated that a reduction of activated $\mathrm{T}$ cells has also been responsible for the effect of infliximab on AIH [6].

Overall, anti-TNF therapy can either ameliorate AIH or induce an immune-mediated liver disease resembling AIH
[95], featuring periportal inflammation as well as elevated serum levels of liver enzymes and anti-nuclear antibodies in a large number of cases [96]. However, patients showed a good response to steroid therapy and failed to relapse after discontinuation of steroid treatment [96]. The paradoxical clinical effects of anti-TNF treatment are possibly due to multiple responses of $\mathrm{CD}^{+}{ }^{+} \mathrm{T}$ cells to TNF. TNF, via TNFR1, pre-dominantly activates the innate immune response including maturation of dendritic cells, thereby priming $\mathrm{CD} 4^{+} \mathrm{T}$ cells [97]. On the other hand, TNF can induce apoptosis of highly activated effector $\mathrm{T}$ cells, thereby determining the pool size of pathogenic conventional T cells [98]. Intriguingly, activation of either TNFR1 or TNFR2 seems to be important for the response of $\mathrm{CD}^{+}{ }^{+} \mathrm{T}$ cells to TNF. In contrast to the ubiquitous expression of TNFR1, TNFR2 expression is restricted to certain cell types including lymphocytes. It is well documented that TNFR2 is preferentially expressed by human and mouse $\mathrm{CD}^{+}{ }^{+}$Foxp $3^{+}$Tregs $[14,15]$. TNFR2 stabilizes Foxp3 by preventing DNA methylation at the Foxp3 promoter, and prevents pathogenic conversion of Tregs under inflammatory conditions [99]. Moreover, TNFR2 increases the suppressive function of Tregs, most likely by induction of their signature molecules CD25, CTLA4, and GITR, as well as Treg survival via induction of Bcl-2, and Treg proliferation (cf. Fig. 2) [14]. In mouse arthritis models, it has been shown that $T n f r 1^{-/-}$mice were protected whereas $T n f r 2^{-/-}$mice displayed disease exacerbation. Accordingly, treatment with either TNFR1 antagonists or TNFR2 agonists ameliorated the disease (Table 2) [15]. Taken together, the disparate function of TNFR1 and TNFR2 in T cell immunity underscores the necessity to selectively analyse their cell-specific role in preclinical mouse models of immune-mediated liver injury and to develop novel therapeutic agents that selectively block TNFR1 and, on the contrary, selectively activate TNFR2 for treatment of autoimmune liver disease.

\section{Primary sclerosing cholangitis (PSC)}

PSC is a chronic cholestatic liver disease characterized by biliary inflammation and progressive fibrosis, end-stage liver disease, and a high risk of malignancy. Current medical treatment of PSC is of limited effectiveness. More than $80 \%$ of PSC patients have IBD with a unique clinical phenotype [100]. Alterations in BA composition and reabsorption of toxic BAs seem to be involved in the pathogenesis of PSC [58], a mechanism which has been recently observed to be regulated by $\mathrm{T}$ cells and inflammatory cytokines in a mouse model [60]. Indeed, PSC has been recognized as an immunemediated biliary disease. A large majority of PSC-associated gene loci involve molecules essential for immune-related pathways. Strong associations are described for HLA loci 
Table 2 Therapeutic effects of next-generation biologicals targeting TNFR1 or TNFR2 in models of autoimmune disease and liver disease ( adapted from 15 and 126)

\begin{tabular}{|c|c|c|}
\hline Agent & Structure & Therapeutic efficacy \\
\hline \multicolumn{3}{|l|}{ TNFR1 antagonists } \\
\hline XPro1595 & $\begin{array}{l}\text { Mutated human sTNF unable to signal through } \\
\text { TNFR1, XENP345: pegylated form }\end{array}$ & EAE, LPS-induced hepatitis, high-fat diet induced insulin resistance \\
\hline R1antTNF & $\begin{array}{l}\text { sTNF mutein, } \\
\text { PEG-R1antTNF: pegylated form }\end{array}$ & ConA- and $\mathrm{CCl}_{4}$-induced hepatitis, EAE, CIA \\
\hline Atrosab & Humanized anti-TNFR1 IgG1 mAb & EAE, CIA, NASH \\
\hline TROS & Trivalent nanobody & EAE, acute huTNF-induced liver inflammation in $\mathrm{uPA}^{+/+}-$SCID mice \\
\hline \multicolumn{3}{|l|}{ TNFR2 agonists } \\
\hline STAR2 & Mouse TNF mutein nanomer & Increased expansion, survival and function of $\mathrm{T}_{\text {regs }}$; CIA, EAE, GvHD \\
\hline EHD2-sc-mTNF $F_{\mathrm{R} 2}$ & Mouse TNF mutein hexamer & Increased expansion of $\mathrm{T}_{\text {regs }} ; \mathrm{CIA}, \mathrm{EAE}$ \\
\hline MR2-1 & Anti-human TNFR2 (mouse mAb) & Increased expansion and stability of $\mathrm{T}_{\text {regs }}$; not tested in vivo \\
\hline
\end{tabular}

$\mathrm{CCl}_{4}$, carbon tetrachloride; $C I A$, collagen-induced arthritis; ConA, concanavalin A; $E A E$, experimental autoimmune encephalomyelitis; $G v H D$, graft-versus-host disease; $L P S$, lipopolysaccharide; $m A b$, monoclonal antibody; $T N F$, tumour necrosis factor; TNFR, TNF receptor; TROS, TNF receptor one silencer

and genes of the interleukin (IL)-2 pathway ( $C D 28, I L-2$, and $I L-2 R A$ ), suggesting that $\mathrm{T}$ cell-dependent adaptive immune responses contribute to the immunopathogenesis of PSC [101]. Recently, these genetic association studies have been reinforced by functional studies indicating failure of activated $\mathrm{CD}^{+} \mathrm{T}$ cell apoptosis [102] and reduced circulating frequencies of Tregs in PSC patients [103]. In addition, gene variation analysis indicated a significant reduction of HLA alleles specific for inhibitory NK cell receptors in patients with PSC [104]. Indeed, circulating and hepatic NK cells from PSC patients harbour a specific phenotype and are enriched in liver tissue $[105,106]$. Moreover, we recently demonstrated that NK cell- and IFN- $\gamma$-dependent immune responses contribute to the pathogenesis of sclerosing cholangitis [105].

Emerging evidence from clinical and preclinical studies indicates the development gut dysbiosis in PSC patients [107] and in mouse models [108, 109]. In addition, these studies point to a role of an inappropriate immune response towards the altered commensal microbiota for PSC disease pathology. For example, an increased Th17 response to biliary pathogens has been observed in PSC patients [110]. Th17 cells are abundant in the intestinal lamina propria where they are induced by commensal bacteria and provide protection against invading pathogens. Pathogenic microbes may induce a dysregulated IL-17 response which is critically involved in IBD [111]. Recently, a single cell atlas of intrahepatic $\mathrm{CD}^{+} \mathrm{T}$ cells of PSC patients has been established, in which single cell sequencing and trajectory analysis provided evidence for expansion of tissue resident $\mathrm{CD}_{4}^{+}$ $\mathrm{T}$ cells exhibiting a phenotype of naïve $\mathrm{T}$ cells that are prone to polarize towards effector Th17 cells [112]. Amongst the 'non-classical' innate-like T cells, resembling mucosal-activated invariant $\mathrm{T}$ cells, three clusters with distinct functional phenotypes were identified, amongst which are Th17 like innate cells, expressing the transcription factor RORA, as well as pro-inflammatory cells, characterized by expression of high levels of TNF [112]. Hence, Th17 cells expressing IL-17, IL-23, and other cytokines as well as T cells and innate lymphocytes expressing IFN $\gamma$ and TNF have been associated with disease pathology of PSC. Several small cohort studies in PSC and PSC/IBD patients analysed the impact of anti-TNF therapies, which seemed to be only moderately effective [113, 114]. It was concluded that the heterogeneity of the phenotype in PSC possibly makes it difficult to draw clear conclusions from studies involving only a small number of patients [113].

Two well-accepted murine models serve as animal models for sclerosing cholangitis. These are (i) the $M d r 2^{-/-}$mouse model, bearing a targeted disruption of the multidrug resistance gene that corresponds to the human orthologue MDR-3 [115] and (ii) the model of 3,5-diethoxycarbonyl-1,4-dihydrocollidine (DDC)-fed wild-type mice [109]. Liver histopathology in these models displays specific morphological features observed in livers of PSC patients, such as biliary inflammation, ductular proliferation, and onion skin type periductal fibrosis. Preclinical studies in these models showed dysbiosis and increased gut permeability in $M d r 2^{-/-}$mice and a good response to antibiotic treatment in DDC-fed animals [109]. Moreover, these mice mounted a hepatic IL-17 response which depended on intestinal pathobionts, epithelial barrier disruption, and bacterial translocation. IL-17 was produced by either $\gamma \delta \mathrm{T}$ cells (in $M d r 2^{-/-}$mice [108]) or Th17 cells (in gnotobiotic DDCfed mice recolonised with faecal samples from PSC/IBD patients [109]).

Enhanced levels of TNF have also been detected in $M d r 2^{-/-}$mice compared to wild-type mice [105]. A 
preclinical functional study in the DDC model indicated that anti-TNF treatment had no effect on serum levels of liver enzymes but prevented the ductular reaction as well as extracellular matrix deposition in mouse livers [116]. We wondered whether TNF would affect liver inflammation, liver damage, and fibrosis in chronic experimental sclerosing cholangitis in the $M d r 2^{-/-}$mouse model. Using $M d r 2^{-1-} \times T n f r 1^{-1-}$ double knockout mice, we observed an aggravated disease pathology of sclerosing cholangitis associated with an increased Th17 response in $M d r 2^{-l-} \times \operatorname{Tnfr}^{-/-}$mice compared to $M d r 2^{-/-}$mice [117]. Moreover, Th17-related chemokine expression (Ccr6 and Cxcr6) and expression of $C c l 2$ and $C x 3 c l l$, which are critically involved in the recruitment of inflammatory monocytes, were also elevated. Accordingly, we observed increased frequencies of $\mathrm{CD} 11 \mathrm{~b}^{+} \mathrm{CX}_{3} \mathrm{CR} 1^{+}$monocytes/ macrophages in livers of $\mathrm{Mdr}^{-/-} \times \mathrm{Tnfr}^{-/-}$mice compared to $M d r 2^{-/-}$mice which changed their phenotype by inappropriately expressing Ripk $3 . \mathrm{CX}_{3} \mathrm{CR} 1^{+} \mathrm{RIPK}^{+}$ macrophages have been recently shown to produce the cytokines IL- $1 \beta$ and IL-23 which promote Th17 responses [118].

Since $M d r 2^{-/-}$mice are a mouse model of inflammation-induced tumour development, and IL-17 has been closely associated with strong induction of regeneration and angiogenesis in the tumour microenvironment [119], we analysed gene expression of cell proliferation markers and known tumour markers of HCC in livers of $\mathrm{Mdr}^{-1-} \times \mathrm{Tnfrl}^{-/-}$compared to control mice. We observed a significant increase of the expression of Pcna (gene of proliferating cell nuclear antigen), Ccna2 (gene of cyclin A2), Cdk1 (gene of cyclin-dependent kinase 1), Sspl (gene of secreted phosphoprotein-1, OPN), and Afp (gene of $\alpha$-feto protein) in the double knockout mice, indicating that they might be more susceptible to development of HCC than $M d r 2^{-/-}$mice. As mentioned earlier, activation of TNFR 1 induces cell survival and liver regeneration by activation of NFKB. Interestingly, targeted disruption of $\mathrm{NFKB}$ signalling specifically in intestinal epithelial cells in the gut resulted in intestinal barrier disruption and chronic colitis, which did not develop under germ-free conditions [120]. Moreover, hepatocyte-specific deletion of IKK $\beta$, a subunit of the kinase complex that activates NFkB (cf. Fig. 1), severely aggravated liver damage and fibrosis in $\mathrm{Mdr}^{-/-}$mice [121]. Therefore, with respect to our study, it seems that TNFR1 might have been responsible for NFkB activation in hepatocytes and in intestinal epithelial cells thereby supporting cell survival and preventing intestinal dysbiosis, intestinal barrier dysfunction, and an inappropriate immune response which aggravates sclerosing cholangitis in a susceptible host.

\section{Role of TNF in hepatocellular carcinoma (HCC)}

Functional evidence for a role of TNF in HCC was provided by studies in mice. Deficiency of the TNFR-dependent anti-apoptotic NFKB signalling pathway was shown to be essential for induction of compensatory proliferation of live hepatocytes in response to hepatocyte death which results in development of HCC [7]. Mice lacking the regulatory subunit of the IKK complex, NEMO, specifically in hepatocytes, spontaneously develop chronic liver disease that progresses to HCC [122] due to increased TNFR1-dependent death of NEMO-deficient hepatocytes [123]. Moreover, hepatocytespecific deletion of IKK $\beta$ exacerbated chemically induced liver cancer in mice, probably by aggravating carcinogeninduced hepatocyte death and induction of compensatory proliferation of hepatocytes [124]. However, inhibition of NFKB activation by anti-TNF treatment or induction of a (transgenic) non-degradable form of IкB at late stages of tumour development in $M d r 2^{-/-}$mice resulted in apoptosis of transformed hepatocytes and lack of progression to HCC [125]. Hence, early TNFR1-inducible NFkB activation associated with reduced hepatocellular death seems to be linked to an inhibition of compensatory hepatocyte proliferation in $M d r 2^{-/-}$mice, indicated by a reduced expression of proliferation and tumour markers [117], while at later time points $\mathrm{NF \kappa B}$ mediates survival of transformed hepatocytes that is responsible for the progression to HCC [125].

\section{Conclusion and therapeutic outlook}

By activation of the ubiquitously expressed TNFR1, TNF provides signals for eradication of pathogens and tissue damage such as inflammation and cell death, but also induces cell survival, proliferation, and tissue regeneration, thereby contributing to resolution of inflammation and tissue repair. Therefore, it is not surprising that antiTNF therapy has major beneficial clinical effects in several autoimmune diseases such as RA and IBD, but also induces adverse effects such as increased susceptibility to infection and more unexpectedly exacerbation of preexisting autoimmune disease (e.g. multiple sclerosis) or even new development of autoimmune-like symptoms in different organs [2, 8]. In the liver, evidence for therapeutic effects of anti-TNF treatment is accumulating, while induction of DILI, autoimmune-like hepatitis, and cholestatic hepatitis have been reported in rare cases that are, however, often reversible after anti-TNF withdrawal [95].

While the role of TNFR1 for liver inflammation, induction of several forms of hepatocyte death, cell survival, 
liver regeneration, hepatocyte proliferation, and tumorigenesis is well documented, the role of TNFR2 for acute and chronic liver injury is scarcely described. A few reports suppose that TNFR2, although devoid of a death domain and primarily activating $\mathrm{NF \kappa B}$, might facilitate TNFR1-induced liver cell death [27, 40], a mechanism which has been described to depend on delocalisation and degradation of TRAF2 and negative regulation of NFKB signalling (reviewed in [2]). However, in view of the immuno-regulatory nature of TNFR2, which plays an important function for Treg stability, immunosuppressive function, and expansion [14, 15], preclinical studies in chronic models of liver injury using TNFR2-deficient or, even more important, cell-specific TNFR2 knockout mice are urgently needed. With respect to therapy of inflammatory and autoimmune liver disease, future trials should investigate the therapeutic efficacy of selective TNFR1 antagonists that inhibit liver inflammation while sparing the suppressive functions of Tregs. On the other hand, activation of TNFR 2 by agonistic antibodies or agonistic TNF muteins that activate, stabilize, and expand Tregs $[15,126]$ could have considerable therapeutic implications for treatment of autoimmune liver disease. A list of next-generation biologicals specifically targeting TNFR1 or TNFR2 in models of autoimmune diseases and liver disease is given in Table 2. In contrast to these considerations, TNFR2 antagonism could be relevant for treatment of cancer, considering that TNFR2 ${ }^{+}$Tregs could suppress the antigen-specific $\mathrm{T}$ cell response against the tumour [127]. Taken together, with respect to successful therapy of inflammatory and autoimmune diseases targeting TNF, a future approach will be selective inhibition or activation of one of the two TNFRs.

Funding Open Access funding enabled and organized by Projekt DEAL. This work was supported by the Deutsche Forschungsgemeinschaft (DFG): SFB 841 project B1 granted to G.T. and A.K.H., and KFO306 project 4 granted to G.T.

\section{Declarations}

Conflict of interest The authors declare no competing interests.

Open Access This article is licensed under a Creative Commons Attribution 4.0 International License, which permits use, sharing, adaptation, distribution and reproduction in any medium or format, as long as you give appropriate credit to the original author(s) and the source, provide a link to the Creative Commons licence, and indicate if changes were made. The images or other third party material in this article are included in the article's Creative Commons licence, unless indicated otherwise in a credit line to the material. If material is not included in the article's Creative Commons licence and your intended use is not permitted by statutory regulation or exceeds the permitted use, you will need to obtain permission directly from the copyright holder. To view a copy of this licence, visit http://creativecommons.org/licenses/by/4.0/.

\section{References}

1. DI Jang, AH Lee, HY Shin, HR Song, JH Park, TB Kang et al (2021) The role of tumor necrosis factor alpha (TNF-alpha) in autoimmune disease and current TNF-alpha inhibitors in therapeutics. Int J Mol Sci 22(5)

2. Brenner D, Blaser H, Mak TW (2015) Regulation of tumour necrosis factor signalling: live or let die. Nat Rev Immunol 15(6):362-3-74

3. Ghabril M, Bonkovsky HL, Kum C, Davern T, Hayashi PH, Kleiner DE et al (2013) Liver injury from tumor necrosis factor-alpha antagonists: analysis of thirty-four cases. Clin Gastroenterol Hepatol 11(5):558-64 e3

4. Bradham CA, Plumpe J, Manns MP, Brenner DA, Trautwein C (1998) Mechanisms of hepatic toxicity I TNF-induced liver injury. Am J Physiol 275(3):G387-92

5. Wullaert A, van Loo G, Heyninck K, Beyaert R (2007) Hepatic tumor necrosis factor signaling and nuclear factorkappaB: effects on liver homeostasis and beyond. Endocr Rev 28(4):365-386

6. Weiler-Normann C, Schramm C, Quaas A, Wiegard C, Glaubke C, Pannicke $\mathrm{N}$ et al (2013) Infliximab as a rescue treatment in difficult-to-treat autoimmune hepatitis. J Hepatol 58(3):529-534

7. Grivennikov SI, Karin M (2011) Inflammatory cytokines in cancer: tumour necrosis factor and interleukin 6 take the stage. Ann Rheum Dis 70(Suppl 1):i104-i108

8. Dostert C, Grusdat M, Letellier E, Brenner D (2019) The TNF family of ligands and receptors: communication modules in the immune system and beyond. Physiol Rev 99(1):115-160

9. Beg AA, Sha WC, Bronson RT, Ghosh S, Baltimore D (1995) Embryonic lethality and liver degeneration in mice lacking the RelA component of NF-kappa B. Nature 376(6536):167-170

10. Yamada Y, Kirillova I, Peschon JJ, Fausto N (1997) Initiation of liver growth by tumor necrosis factor: deficient liver regeneration in mice lacking type I tumor necrosis factor receptor. Proc Natl Acad Sci U S A 94(4):1441-1446

11. Yamada Y, Webber EM, Kirillova I, Peschon JJ, Fausto N (1998) Analysis of liver regeneration in mice lacking type 1 or type 2 tumor necrosis factor receptor: requirement for type 1 but not type 2 receptor. Hepatology 28(4):959-970

12. Aggarwal BB (2003) Signalling pathways of the TNF superfamily: a double-edged sword. Nat Rev Immunol 3(9):745-756

13. Bradham CA, Qian T, Streetz K, Trautwein C, Brenner DA, Lemasters JJ (1998) The mitochondrial permeability transition is required for tumor necrosis factor alpha-mediated apoptosis and cytochrome c release. Mol Cell Biol 18(11):6353-6364

14. Chen X, Oppenheim JJ (2011) Resolving the identity myth: key markers of functional CD4+FoxP3+ regulatory T cells. Int Immunopharmacol 11(10):1489-1496

15. Salomon BL (2021) Insights into the biology and therapeutic implications of TNF and regulatory T cells. Nat Rev Rheumatol 17(8):487-504

16. EA Carswell, LJ Old, RL Kassel, S Green, N Fiore, B Williamson (1975) An endotoxin-induced serum factor that causes tumor necrosis. Proc Natl Acad Sci USA 72

17. Lehmann V, Freudenberg MA, Galanos C (1987) Lethal toxicity of lipopolysaccharide and tumor necrosis factor in normal and D-galactosamine-treated mice. J Exp Med 165(3):657-663

18. Tiegs G, Wolter M, Wendel A (1989) Tumor necrosis factor is a terminal mediator in galactosamine endotoxin-induced hepatitis in mice. Biochem Pharmacol 38(4):627-631

19 Keppler DO, Pausch J, Decker K (1974) Selective uridine triphosphate deficiency induced by D-galactosamine in liver and reversed by pyrimidine nucleotide precursors. Effect on ribonucleic acid synthesis. J Biol Chem 249(1):211-6 
20. Leist M, Gantner F, Bohlinger I, Germann PG, Tiegs G, Wendel A (1994) Murine hepatocyte apoptosis induced in vitro and in vivo by TNF-alpha requires transcriptional arrest. J Immunol 153(4):1778-1788

21. Pfeffer K, Matsuyama T, Kundig TM, Wakeham A, Kishihara K, Shahinian A et al (1993) Mice deficient for the $55 \mathrm{kd}$ tumor necrosis factor receptor are resistant to endotoxic shock yet succumb to L monocytogenes infection. Cell 73(3):457-67

22. Leist M, Gantner F, Jilg S, Wendel A (1995) Activation of the 55-Kda Tnf receptor is necessary and sufficient for Tnf-induced liver-failure, hepatocyte apoptosis, and nitrite release. J Immunol 154(3):1307-1316

23. Sass G, Shembade ND, Haimerl F, Lamoureux N, Hashemolhosseini S, Tannapfel A et al (2007) TNF pretreatment interferes with mitochondrial apoptosis in the mouse liver by A20-mediated down-regulation of Bax. J Immunol 179(10):7042-7049

24. Sass G, Shembade ND, Tiegs G (2005) Tumour necrosis factor alpha (TNF)-TNF receptor 1-inducible cytoprotective proteins in the mouse liver: relevance of suppressors of cytokine signalling. Biochem J 385(Pt 2):537-544

25. Sieber S, Lange N, Kollmorgen G, Erhardt A, Quaas A, Gontarewicz A et al (2012) Sharpin contributes to TNFalpha dependent NFkappaB activation and anti-apoptotic signalling in hepatocytes. PLoS One 7(1):e29993

26. Koerber K, Sass G, Kiemer AK, Vollmar AM, Tiegs G (2002) In vivo regulation of inducible NO synthase in immune-mediated liver injury in mice. Hepatology 36(5):1061-1069

27. Kusters S, Tiegs G, Alexopoulou L, Pasparakis M, Douni E, Kunstle G et al (1997) In vivo evidence for a functional role of both tumor necrosis factor (TNF) receptors and transmembrane TNF in experimental hepatitis. Eur J Immunol 27(11):2870-2875

28. Tiegs G, Hentschel J, Wendel A (1992) A T cell-dependent experimental liver injury in mice inducible by concanavalin A. J Clin Invest 90(1):196-203

29. Toyabe S, Seki S, Iiai T, Takeda K, Shirai K, Watanabe H et al (1997) Requirement of IL-4 and liver NK1+ T cells for concanavalin A-induced hepatic injury in mice. J Immunol 159(3):1537-1542

30. Gantner F, Leist M, Lohse AW, Germann PG, Tiegs G (1995) Concanavalin A-induced T-cell-mediated hepatic injury in mice: the role of tumor necrosis factor. Hepatology 21(1):190-198

31. Kunstle G, Hentze H, Germann PG, Tiegs G, Meergans T, Wendel A (1999) Concanavalin A hepatotoxicity in mice: tumor necrosis factor-mediated organ failure independent of caspase3-like protease activation. Hepatology 30(5):1241-1251

32. Streetz K, Fregien B, Plumpe J, Korber K, Kubicka S, Sass G et al (2001) Dissection of the intracellular pathways in hepatocytes suggests a role for Jun kinase and IFN regulatory factor-1 in Con A-induced liver failure. J Immunol 167(1):514-523

33. Liedtke C, Bangen JM, Freimuth J, Beraza N, Lambertz D, Cubero FJ et al (2011) Loss of caspase- 8 protects mice against inflammation-related hepatocarcinogenesis but induces nonapoptotic liver injury. Gastroenterology 141(6):2176-2187

34. Maeda S, Chang L, Li Z-W, Luo J-L, Leffert H, Karin M (2003) IKK $\beta$ is required for prevention of apoptosis mediated by cellbound but not by circulating TNF $\alpha$. Immunity 19(5):725-737

35. Seki E, Brenner DA, Karin M (2012) A liver full of JNK: signaling in regulation of cell function and disease pathogenesis, and clinical approaches. Gastroenterology 143(2):307-320

36. Arshad MI, Rauch M, Ĺhelgoualćh A, Julia V, Leite-de-Moraes MC, Lucas-Clerc C et al (2011) NKT cells are required to induce high IL-33 expression in hepatocytes during ConA-induced acute hepatitis. Eur J Immunol 41(8):2341-8

37. Neumann K, Karimi K, Meiners J, Voetlause R, Steinmann S, Dammermann W et al (2017) A proinflammatory role of type 2 innate lymphoid cells in murine immune-mediated hepatitis. J Immunol 198(1):128-137

38 Arshad MI, Piquet-Pellorce C, Filliol A, Ĺhelgoualćh A, LucasClerc C, Jouan-Lanhouet $S$ et al (2015) The chemical inhibitors of cellular death, PJ34 and Necrostatin-1, down-regulate IL-33 expression in liver. J Mol Med (Berl) 93(8):867-78

39. Douni E, Kollias G (1998) A critical role of the p75 tumor necrosis factor receptor (p75TNF-R) in organ inflammation independent of TNF, lymphotoxin alpha, or the p55TNF-R. J Exp Med 188(7):1343-1352

40. Schumann J, Muhlen K, Kiemer AK, Vollmar AM, Tiegs G (2003) Parenchymal, but not leukocyte, TNF receptor 2 mediates T cell-dependent hepatitis in mice. J Immunol 170(4):2129-2137

41. Fotin-Mleczek M, Henkler F, Samel D, Reichwein M, Hausser A, Parmryd I et al (2002) Apoptotic crosstalk of TNF receptors: TNF-R2-induces depletion of TRAF2 and IAP proteins and accelerates TNF-R1-dependent activation of caspase-8. J Cell Sci 115(Pt 13):2757-2770

42. Kubes P, Mehal WZ (2012) Sterile inflammation in the liver. Gastroenterol 143(5):1158-1172

43. Lee WM (2007) Acetaminophen toxicity: changing perceptions on a social/medical issue. Hepatol 46(4):966-970

44. Ramachandran A, McGill MR, Xie Y, Ni HM, Ding WX, Jaeschke H (2013) Receptor interacting protein kinase 3 is a critical early mediator of acetaminophen-induced hepatocyte necrosis in mice. Hepatol 58(6):2099-2108

45. Jaeschke H, Williams CD, Ramachandran A, Bajt ML (2012) Acetaminophen hepatotoxicity and repair: the role of sterile inflammation and innate immunity. Liver Int 32(1):8-20

46. Boess F, Bopst M, Althaus R, Polsky S, Cohen SD, Eugster HP et al (1998) Acetaminophen hepatotoxicity in tumor necrosis factor/lymphotoxin-alpha gene knockout mice. Hepatol 27(4):1021-1029

47. Chiu H, Gardner CR, Dambach DM, Durham SK, Brittingham JA, Laskin JD et al (2003) Role of tumor necrosis factor receptor 1 (p55) in hepatocyte proliferation during acetaminophen-induced toxicity in mice. Toxicol Appl Pharmacol 193(2):218-227

48. Gao B, Bataller R (2011) Alcoholic liver disease: pathogenesis and new therapeutic targets. Gastroenterol 141(5):1572-1585

49. Roychowdhury S, McMullen MR, Pisano SG, Liu X, Nagy LE (2013) Absence of receptor interacting protein kinase 3 prevents ethanol-induced liver injury. Hepatol 57(5):1773-1783

50. Iimuro Y, Gallucci RM, Luster MI, Kono H, Thurman RG (1997) Antibodies to tumor necrosis factor alfa attenuate hepatic necrosis and inflammation caused by chronic exposure to ethanol in the rat. Hepatol 26(6):1530-1537

51. Yin M, Wheeler MD, Kono H, Bradford BU, Gallucci RM, Luster MI et al (1999) Essential role of tumor necrosis factor alpha in alcohol-induced liver injury in mice. Gastroenterol 117(4):942-952

52. Boetticher NC, Peine CJ, Kwo P, Abrams GA, Patel T, Aqel B et al (2008) A randomized, double-blinded, placebo-controlled multicenter trial of etanercept in the treatment of alcoholic hepatitis. Gastroenterol 135(6):1953-1960

53. Lee YA, Friedman SL (2022) Inflammatory and fibrotic mechanisms in NAFLD-Implications for new treatment strategies. J Intern Med 291(1):11-31. https://doi.org/10.1111/joim.13380

54. Gautheron J, Gores GJ, Rodrigues CMP (2020) Lytic cell death in metabolic liver disease. J Hepatol 73(2):394-408

55. Mridha AR, Wree A, Robertson AAB, Yeh MM, Johnson CD, Van Rooyen DM et al (2017) NLRP3 inflammasome blockade reduces liver inflammation and fibrosis in experimental NASH in mice. J Hepatol 66(5):1037-1046 
56. Lefere S, Tacke F (2019) Macrophages in obesity and nonalcoholic fatty liver disease: crosstalk with metabolism. JHEP Rep 1(1):30-43

57. Gomes AL, Teijeiro A, Buren S, Tummala KS, Yilmaz M, Waisman A et al (2016) Metabolic inflammation-associated IL-17A causes non-alcoholic steatohepatitis and hepatocellular carcinoma. Cancer Cell 30(1):161-175

58. Evangelakos I, Heeren J, Verkade E, Kuipers F (2021) Role of bile acids in inflammatory liver diseases. Semin Immunopathol 43(4):577-590

59. Puri P, Daita K, Joyce A, Mirshahi F, Santhekadur PK, Cazanave $S$ et al (2018) The presence and severity of nonalcoholic steatohepatitis is associated with specific changes in circulating bile acids. Hepatol 67(2):534-548

60. Glaser F, John C, Engel B, Hoh B, Weidemann S, Dieckhoff J et al (2019) Liver infiltrating $\mathrm{T}$ cells regulate bile acid metabolism in experimental cholangitis. J Hepatol 71(4):783-792

61. Trauner M, Fuchs CD (2021) Novel therapeutic targets for cholestatic and fatty liver disease. Gut.

62. Uysal KT, Wiesbrock SM, Marino MW, Hotamisligil GS (1997) Protection from obesity-induced insulin resistance in mice lacking TNF-alpha function. Nature 389(6651):610-614

63. Kirchgessner TG, Uysal KT, Wiesbrock SM, Marino MW, Hotamisligil GS (1997) Tumor necrosis factor-alpha contributes to obesity-related hyperleptinemia by regulating leptin release from adipocytes. J Clin Invest 100(11):2777-2782

64. Abiru S, Migita K, Maeda Y, Daikoku M, Ito M, Ohata K et al (2006) Serum cytokine and soluble cytokine receptor levels in patients with non-alcoholic steatohepatitis. Liver Int 26(1):39-45

65. Potoupni V, Georgiadou M, Chatzigriva E, Polychronidou G, Markou E, Zapantis Gakis C et al. (2021) Circulating tumor necrosis factor-alpha levels in non-alcoholic fatty liver disease: a systematic review and a meta-analysis. J Gastroenterol Hepatol.

66. Crespo J, Cayon A, Fernandez-Gil P, Hernandez-Guerra M, Mayorga M, Dominguez-Diez A et al (2001) Gene expression of tumor necrosis factor alpha and TNF-receptors, p55 and p75, in nonalcoholic steatohepatitis patients. Hepatol 34(6):1158-1163

67. Tomita K, Tamiya G, Ando S, Ohsumi K, Chiyo T, Mizutani A et al (2006) Tumour necrosis factor alpha signalling through activation of Kupffer cells plays an essential role in liver fibrosis of non-alcoholic steatohepatitis in mice. Gut 55(3):415-424

68. Wandrer F, Liebig S, Marhenke S, Vogel A, John K, Manns MP et al (2020) TNF-Receptor-1 inhibition reduces liver steatosis, hepatocellular injury and fibrosis in NAFLD mice. Cell Death Dis 11(3):212

69. Schramm C, Schneider A, Marx A, Lohse AW (2008) Adalimumab could suppress the activity of non alcoholic steatohepatitis (NASH). Z Gastroenterol 46(12):1369-1371

70. Chisari FV, Ferrari C (1995) Hepatitis B virus immunopathogenesis. Annu Rev Immunol 13:29-60

71. Valaydon Z, Pellegrini M, Thompson A, Desmond P, Revill P, Ebert G (2016) The role of tumour necrosis factor in hepatitis B infection: Jekyll and Hyde. Clin Transl Immunol 5(12):e115

72. Su F, Schneider RJ (1997) Hepatitis B virus HBx protein sensitizes cells to apoptotic killing by tumor necrosis factor alpha. Proc Natl Acad Sci U S A 94(16):8744-8749

73. Jia B, Guo M, Li G, Yu D, Zhang X, Lan K et al (2015) Hepatitis B virus core protein sensitizes hepatocytes to tumor necrosis factor-induced apoptosis by suppression of the phosphorylation of mitogen-activated protein kinase kinase 7 . J Virol 89(4):2041-2051

74. Puro R, Schneider RJ (2007) Tumor necrosis factor activates a conserved innate antiviral response to hepatitis B virus that destabilizes nucleocapsids and reduces nuclear viral DNA. J Virol 81(14):7351-7362
75. Biermer M, Puro R, Schneider RJ (2003) Tumor necrosis factor alpha inhibition of hepatitis $\mathrm{B}$ virus replication involves disruption of capsid Integrity through activation of NF-kappaB. J Virol 77(7):4033-4042

76. Park YK, Park ES, Kim DH, Ahn SH, Park SH, Lee AR et al (2016) Cleaved c-FLIP mediates the antiviral effect of TNFalpha against hepatitis B virus by dysregulating hepatocyte nuclear factors. J Hepatol 64(2):268-277

77. Park J, Kang W, Ryu SW, Kim WI, Chang DY, Lee DH et al (2012) Hepatitis $C$ virus infection enhances TNFalpha-induced cell death via suppression of NF-kappaB. Hepatol 56(3):831-840

78. Xu H, Li H, Cao D, Wu Y, Chen Y (2014) Tumor necrosis factor alpha (TNF-alpha) receptor-I is required for TNF-alpha-mediated fulminant virus hepatitis caused by murine hepatitis virus strain-3 infection. Immunol Lett 158(1-2):25-32

79. Farooq M, Filliol A, Simoes Eugenio M, Piquet-Pellorce C, Dion S, Raguenes-Nicol C et al (2019) Depletion of RIPK1 in hepatocytes exacerbates liver damage in fulminant viral hepatitis. Cell Death Dis 10(1): 12

80. Lampl S, Janas MK, Donakonda S, Brugger M, Lohr K, Schneider A et al (2020) Reduced mitochondrial resilience enables non-canonical induction of apoptosis after TNF receptor signaling in virus-infected hepatocytes. J Hepatol 73(6):1347-1359

81. Suresh M, Singh A, Fischer C (2005) Role of tumor necrosis factor receptors in regulating CD8 T-cell responses during acute lymphocytic choriomeningitis virus infection. J Virol 79(1):202-213

82. Beyer M, Abdullah Z, Chemnitz JM, Maisel D, Sander J, Lehmann C et al (2016) Tumor-necrosis factor impairs CD4(+) $\mathrm{T}$ cell-mediated immunological control in chronic viral infection. Nat Immunol 17(5):593-603

83. Ebert G, Preston S, Allison C, Cooney J, Toe JG, Stutz MD et al (2015) Cellular inhibitor of apoptosis proteins prevent clearance of hepatitis B virus. Proc Natl Acad Sci U S A 112(18):5797-5802

84. Ebert G, Allison C, Preston S, Cooney J, Toe JG, Stutz MD et al (2015) Eliminating hepatitis B by antagonizing cellular inhibitors of apoptosis. Proc Natl Acad Sci U S A 112(18):5803-5808

85. Chyuan IT, Tsai HF, Tzeng HT, Sung CC, Wu CS, Chen PJ et al (2015) Tumor necrosis factor-alpha blockage therapy impairs hepatitis B viral clearance and enhances T-cell exhaustion in a mouse model. Cell Mol Immunol 12(3):317-325

86. de Boer YS, van Gerven NM, Zwiers A, Verwer BJ, van Hoek B, van Erpecum KJ et al (2014) Genome-wide association study identifies variants associated with autoimmune hepatitis type 1 . Gastroenterol 147(2):443-52 e5

87. Cordell HJ, Fryett JJ, Ueno K, Darlay R, Aiba Y, Hitomi Y et al (2021) An international genome-wide meta-analysis of primary biliary cholangitis: Novel risk loci and candidate drugs. J Hepatol 75(3):572-581

88. Gantner F, Leist M, Jilg S, Germann PG, Freudenberg MA, Tiegs G (1995) Tumor necrosis factor-induced hepatic DNA fragmentation as an early marker of T-cell-dependent liver-injury in mice. Gastroenterol 109(1):166-176

89. Schumann J, Angermuller S, Bang R, Lohoff M, Tiegs G (1998) Acute hepatotoxicity of Pseudomonas aeruginosa exotoxin A in mice depends on T cells and TNF. J Immunol 161(10):5745-5754

90. Dimopoulou D, Dimitroulas T, Akriviadis E, Garyfallos A (2015) Infliximab as a treatment option for patients with rheumatoid arthritis and primary biliary cirrhosis. Rheumatol Int 35(11):1913-1916

91. Bakula M, Mayer M, Cikes N, Anic B (2015) A patient with rheumatoid arthritis and primary biliary cirrhosis successfully treated with adalimumab. Lijec Vjesn 137(1-2):27-29 
92. Bovensiepen CS, Schakat M, Sebode M, Zenouzi R, Hartl J, Peiseler M et al (2019) TNF-producing Th1 cells are selectively expanded in liver infiltrates of patients with autoimmune hepatitis. J Immunol 203(12):3148-3156

93. Czaja AJ, Cookson S, Constantini PK, Clare M, Underhill JA, Donaldson PT (1999) Cytokine polymorphisms associated with clinical features and treatment outcome in type 1 autoimmune hepatitis. Gastroenterol 117(3):645-652

94. Billmeier U, Dieterich W, Neurath MF, Atreya R (2016) Molecular mechanism of action of anti-tumor necrosis factor antibodies in inflammatory bowel diseases. World J Gastroenterol 22(42):9300-9313

95. LR Lopetuso, G Mocci, M Marzo, F D’aversa, GL Rapaccini, L Guidi et al. (2018) Harmful effects and potential benefits of anti-tumor necrosis factor (TNF)-alpha on the liver. Int J Mol Sci 19(8).

96. Bjornsson HK, Gudbjornsson B, Bjornsson ES (2022) Infliximab-induced liver injury: clinical phenotypes, autoimmunity and the role of corticosteroid treatment. J Hepatol 76(1):86-92

97. Kollias G, Kontoyiannis D, Douni E, Kassiotis G (2002) The role of TNF/TNFR in organ-specific and systemic autoimmunity: implications for the design of optimized 'anti-TNF' therapies. Curr Dir Autoimmun 5:30-50

98. Mehta AK, Gracias DT, Croft M (2018) TNF activity and T cells. Cytokine 101:14-18

99. Tseng WY, Huang YS, Clanchy F, McNamee K, Perocheau $\mathrm{D}$, Ogbechi $\mathrm{J}$ et al (2019) TNF receptor 2 signaling prevents DNA methylation at the Foxp3 promoter and prevents pathogenic conversion of regulatory T cells. Proc Natl Acad Sci U S A 116(43):21666-21672

100. Little R, Wine E, Kamath BM, Griffiths AM, Ricciuto A (2020) Gut microbiome in primary sclerosing cholangitis: A review. World J Gastroenterol 26(21):2768-2780

101. Lazaridis KN, LaRusso NF (2016) Primary sclerosing cholangitis. N Engl J Med 375(25):2501-2502

102. Schoknecht T, Schwinge D, Stein S, Weiler-Normann C, Sebode M, Mucha S et al (2017) CD4+ T cells from patients with primary sclerosing cholangitis exhibit reduced apoptosis and downregulation of proapoptotic Bim in peripheral blood. J Leukoc Biol 101(2):589-597

103. Sebode M, Peiseler M, Franke B, Schwinge D, Schoknecht T, Wortmann F et al (2014) Reduced FOXP3(+) regulatory T cells in patients with primary sclerosing cholangitis are associated with IL2RA gene polymorphisms. J Hepatol 60(5):1010-1016

104. Karlsen TH, Boberg KM, Olsson M, Sun JY, Senitzer D, Bergquist A et al (2007) Particular genetic variants of ligands for natural killer cell receptors may contribute to the HLA associated risk of primary sclerosing cholangitis. J Hepatol 46(5):899-906

105. Ravichandran G, Neumann K, Berkhout LK, Weidemann S, Langeneckert AE, Schwinge D et al (2019) Interferon-gammadependent immune responses contribute to the pathogenesis of sclerosing cholangitis in mice. J Hepatol 71(4):773-782

106. Langeneckert AE, Lunemann S, Martrus G, Salzberger W, Hess LU, Ziegler AE et al (2019) CCL21-expression and accumulation of CCR7 $(+)$ NK cells in livers of patients with primary sclerosing cholangitis. Eur J Immunol 49(5):758-769

107 Kummen M, Thingholm LB, Ruhlemann MC, Holm K, Hansen SH, Moitinho-Silva L et al (2021) Altered gut microbial metabolism of essential nutrients in primary sclerosing cholangitis. Gastroenterol 160(5):1784-98e0
108. Tedesco D, Thapa M, Chin CY, Ge Y, Gong M, Li J et al (2018) Alterations in intestinal microbiota lead to production of interleukin 17 by intrahepatic gammadelta T-cell receptor-positive cells and pathogenesis of cholestatic liver disease. Gastroenterol 154(8):2178-2193

109. Nakamoto N, Sasaki N, Aoki R, Miyamoto K, Suda W, Teratani T et al (2019) Gut pathobionts underlie intestinal barrier dysfunction and liver T helper 17 cell immune response in primary sclerosing cholangitis. Nat Microbiol 4(3):492-503

110. Katt J, Schwinge D, Schoknecht T, Quaas A, Sobottka I, Burandt $E$ et al (2013) Increased $T$ helper type 17 response to pathogen stimulation in patients with primary sclerosing cholangitis. Hepatol 58(3): 1084-1093

111. Stockinger B, Omenetti S (2017) The dichotomous nature of T helper 17 cells. Nat Rev Immunol 17(9):535-44

112. Poch T, Krause J, Casar C, Liwinski T, Glau L, Kaufmann M et al (2021) Single-cell atlas of hepatic T cells reveals expansion of liver-resident naive-like CD4(+) T cells in primary sclerosing cholangitis. J Hepatol 75(2):414-423

113. Lynch KD, Keshav S, Chapman RW (2019) The use of biologics in patients with inflammatory bowel disease and primary sclerosing cholangitis. Curr Hepatol Rep 18(1):115-126

114. Hedin CRH, Sado G, Ndegwa N, Lytvyak E, Mason A, MontanoLoza A et al (2020) Effects of tumor necrosis factor antagonists in patients with primary sclerosing cholangitis. Clin Gastroenterol Hepatol 18(10):2295-304 e2

115. Fickert P, Fuchsbichler A, Wagner M, Zollner G, Kaser A, Tilg $\mathrm{H}$ et al (2004) Regurgitation of bile acids from leaky bile ducts causes sclerosing cholangitis in Mdr2 (Abcb4) knockout mice. Gastroenterol 127(1):261-274

116. Verhulst S, Best J, Syn WK, Reynaert H, Hellemans KH, Canbay A et al (2016) Infliximab and dexamethasone attenuate the ductular reaction in mice. Sci Rep 6:36586

117. Berkhout L, Barikbin R, Schiller B, Ravichandran G, Krech T, Neumann K et al (2019) Deletion of tumour necrosis factor alpha receptor 1 elicits an increased TH17 immune response in the chronically inflamed liver. Sci Rep 9(1):4232

118. Moriwaki K, Balaji S, Bertin J, Gough PJ, Chan FK (2017) Distinct kinase-independent role of RIPK3 in CD11c(+) mononuclear phagocytes in cytokine-induced tissue repair. Cell Rep 18(10):2441-2451

119. Kempski J, Brockmann L, Gagliani N, Huber S (2017) TH17 cell and epithelial cell crosstalk during inflammatory bowel disease and carcinogenesis. Front Immunol 8:1373

120. Nenci A, Becker C, Wullaert A, Gareus R, van Loo G, Danese S et al (2007) Epithelial NEMO links innate immunity to chronic intestinal inflammation. Nature 446(7135):557-561

121. Ehlken H, Kondylis V, Heinrichsdorff J, Ochoa-Callejero L, Roskams T, Pasparakis M (2011) Hepatocyte IKK2 protects Mdr2-/- mice from chronic liver failure. PLoS One 6(10):e25942

122. Luedde T, Beraza N, Kotsikoris V, van Loo G, Nenci A, De Vos $R$ et al (2007) Deletion of NEMO/IKKgamma in liver parenchymal cells causes steatohepatitis and hepatocellular carcinoma. Cancer Cell 11(2):119-132

123. Cubero FJ, Singh A, Borkham-Kamphorst E, Nevzorova YA, Al Masaoudi M, Haas U et al (2013) TNFR1 determines progression of chronic liver injury in the IKKgamma/Nemo genetic model. Cell Death Differ 20(11):1580-1592

124. Maeda S, Kamata H, Luo JL, Leffert H, Karin M (2005) IKKbeta couples hepatocyte death to cytokine-driven compensatory 
proliferation that promotes chemical hepatocarcinogenesis. Cell 121(7):977-990

125. Pikarsky E, Porat RM, Stein I, Abramovitch R, Amit S, Kasem $S$ et al (2004) NF-kappaB functions as a tumour promoter in inflammation-associated cancer. Nature 431(7007):461-466

126. Fischer R, Kontermann RE, Pfizenmaier K (2020) Selective targeting of TNF receptors as a novel therapeutic approach. Front Cell Dev Biol 8:401

127. Y Nie, J He, H Shirota, AL Trivett, Yang, DM Klinman et al (2018) Blockade of TNFR2 signaling enhances the immunotherapeutic effect of $\mathrm{CpG}$ ODN in a mouse model of colon cancer. Sci Signal 11(511)

Publisher's note Springer Nature remains neutral with regard to jurisdictional claims in published maps and institutional affiliations. 